\title{
Bonialian, Mariano Alberto. La América Española: entre el Pacífico y elAtlántico. Globalización mercantil y economía política, 1540-1840. Ciudad de México: El Colegio de México, 2019, 446 pp.
}

En décadas recientes la llamada World History o Global History pretende sintetizar el pasado de todas las sociedades en una única narrativa o estudiar un tema o período histórico desde una perspectiva mundial. En este contexto historiográfico, Mariano Bonialian hace notar la notable ausencia «de una agencia propia en Hispanoamérica que no es reconocida en la historia global», y para subsanarla propone en su libro una historia de la economía política americanas desde 1580 a 1840 (16). En los siglos estudiados por Bonialian, la globalización americana se dividió en dos fases oceánicas: primero, un "Atlántico pacificado" en el cual la economía del Pacífico tenía capacidad para actuar sobre el mundo atlántico, seguido por «la atlantización del Pacifico» cuando comerciantes del Atlántico norte "controlan los circuitos del Pacífico» (25). De estas dinámicas oceánicas, participan ejes geohistóricos supraregionales terrestres y marítimos, en torno a los cuales se organizaban los intercambios económicos y culturales.

El monopolio imperial implicaba una oferta de mercancías inferior a la demanda de los virreinatos, lo que permitía a comerciantes peninsulares y americanos un alto nivel de precios y beneficios. En este régimen comercial, las flotas y el galeón de Manila se complementaban: las élites adquirían las ropas y tejidos europeos de calidad llegados a Veracruz, mientras que los sectores populares compraban los tejidos más baratos de los cargamentos llegados a Acapulco.

Cronológicamente, los dos primeros ejes de la América hispana fueron el peruano y el novohispano. El eje peruano que se extendió desde la segunda mitad del siglo XVI hasta 1620, o posiblemente 1640, se centraba en Panamá, cuya ruta terrestre conectaba los galeones llegados de Espańa con la Armada del Sur. Los comerciantes de Lima que controlaban este eje a menudo enviaban agentes a Espaňa —indicando 
así la influencia del Pacífico sobre los circuitos atlánticos—o factores a Filipinas donde encargaban a mercaderes chinos los diseños occidentales demandados en el mercado peruano. Los principales productos exportados desde Acapulco a Perú eran sedas procedentes de Filipinas y telas europeas llegadas por Veracruz. Por su capacidad de importación y distribución, la ciudad de México ocupaba una posición nodal en estos circuitos comerciales. A cambio de textiles, los peruanos enviaban plata, azogue de Huancavelica y cacao de Guayaquil. En los territorios australes, las mercancías extranjeras llegaban a Santiago de Chile y siguiendo la vía Tucumán-Córdoba alcanzaban el área del Río de La Plata. En estas rutas, se sitúan los comerciantes portugueses que exportaban metal precioso por Buenos Aires, Sacramento, costas de Brasil e incluso Portobelo.

Desde 1680 a 1740, a la primacía peruana sucedió el eje novohispano controlado por el Consulado de México. Sus comerciantes organizaban el mercado de bienes y plata en el virreinato acumulando grandes beneficios. Perú siguió enviando plata, azogue y vinos, pero ahora es el cacao de Guayaquil la principal mercancía exportada. México se insertaba en tres circuitos comerciales: las flotas llegadas a Veracruz, el galeón de Manila — ambos legales_ y el circuito del Caribe. De tal forma, que durante estos primeros siglos el Pacífico se mantuvo como un lago indiano bajo el control de los comerciantes de Lima primero y de la Ciudad de México a continuación.

En América, «al inicio de la segunda mitad del siglo XVIII se registra un parteaguas, una suerte de revolución en el comercio, en la cultura del consumo y un proceso de fragmentación de los mercados» (30). Esta ruptura consecuencia de un crecimiento descentralizado de la población en Hispanoámerica generó un nuevo "paradigma consumidor», adquiriendo los compradores americanos una posición de primacía. El consumidor adquiere, desde entonces, una gran cuota de decisión sobre qué productos deben ofrecer los comerciantes españoles en un escenario mercantil donde prima la abundancia y la competencia. De hecho, la política comercial de los Borbones corresponde a la relevancia de élites locales y de mercados regionales, cuya demanda cobra una importancia primordial en medio de una cultura del consumo. 
Para adaptarse a los nuevos tiempos, la monarquía borbónica estableció el llamado «libre comercio», abriéndose un número de puertos en América y en España para comerciar entre ambos continentes. Cesaron las ferias de Portobelo, más tarde se cancelaron las flotas de Veracruz y el tráfico del galeón declinó notablemente obstaculizado por las iniciativas oficiales. La fundación de la Real Compañía de Filipinas culminó los intentos de la Corona para controlar el comercio transpacífico; prueba de ello es que los textiles hindúes llegaban a México por la vía de Panamá, sustituyendo a los anteriormente llegados en el galeón. Una muestra de la prevalencia del Atlántico es que a partir de 1766, en el área del Caribe, el contrabando desde Jamaica hacia puertos de la América española suponía unos seis millones de pesos anuales. Los ingleses comerciaban con algodones, seda y el casimir (cashmere), llegado del Tibet, de la India o de Xinjiang en China, lo cual indica los diversos orígenes de las mercancías y la importancia de la demanda americana.

Globalmente, la revolución industrial de Inglaterra y su Imperio del algodón reorganizaron la geografía mercantil de los virreinatos en torno a la vía abierta por el Cabo de Hornos, iniciada en 1739 por los llamados navíos «de registro» espańoles, seguidos desde 1790 por embarcaciones británicas o angloamericanas. En este tercer eje histórico, Gran Bretaňa y los recientes Estados Unidos iniciaron un comercio global en el cual se incluyen las costas del Atlántico, del Pacífico y los mercados chinos. A consecuencia de las nuevas dinámicas económicas, los mercados se fragmentaron y regionalizaron, lo cual explica la fundación de consulados en numerosas ciudades y la creación de nuevas casas de moneda. $\mathrm{Al}$ mismo tiempo, en el norte del Pacífico, rusos, ingleses y americanos participaban activamente en el comercio de pieles de gran importancia en la articulación económica del oceáno.

Un índice de la radical transformación en la economía mundial es el declive de China como principal importador de plata. Europeos y norteamericanos controlaban los flujos metaliferos que se exportaban desde el Pacífico y Atlántico hispanoamericanos hacia sus países. La pérdida de importancia del imperio chino contrasta con al ascenso de la India «como espacio asiático representativo de la economía global» (313). La Guerra 
del Opio (1839-1842) señaló el final de una relación comercial conflictiva entre Gran Bretaňa y China y la sumisión del Imperio Manchú a los designios extranjeros.

A partir del descubrimiento del oro en California en 1848 y la inauguración del ferrocarril a través del istmo de Panamá en 1855, se establece una red comercial en la cual la costa mexicana del Pacífico mediaba entre Europa, Panamá y San Francisco y cuyo estudio va más allá de la cronología propuesta por el autor.

El punto de partida del estudio de Boinalian es la globalización entendida como un transcurrir a través de los siglos que integra progresivamente nuevas macroregiones en un entramado de relaciones. En esta cronología, sitúa el autor los virreinatos creando un mapa del tiempo por medio de la «caja de herramientas» de los ejes geohistóricos — «estructuras suprarregioanles poco cambiantes»—a través de los cuales América interactúa con el resto del globo. La riqueza del análisis propuesto continúa los númerosos estudios de Bonialian sobre el comercio colonial, pero a la vez es una crucial indicación de la necesidad de situar los estudios locales, regionales o nacionales en un marco planetario. En la «oleada discursiva de la Global History» Bonialian, desde el comercio americano, ha situado la «agencia» del continente con económica claridad. Ensamblando en el texto documentación de archivos y fuentes secundarias junto con un apéndice documental, el libro es indispensable para los historiadores de la Global History y para todos los que cultivan más especificamente la historia hispanoamericana.

Arturo Giráldez University of the Pacific, (Stockton-CA) 